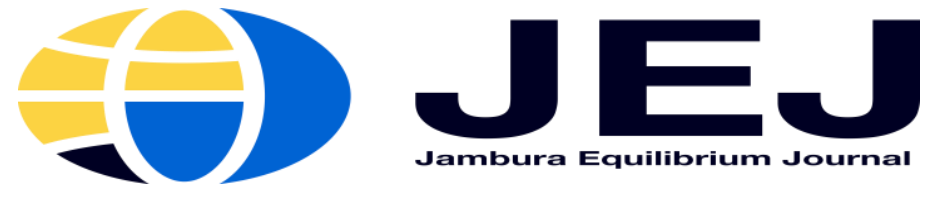

Volume 1. Issue 1. January 2019

P-ISSN 2655-9110

http://ejurnal.ung.ac.id/index.php/equij

\title{
Analysis of Regional Economic Competitiveness of Gorontalo Province (Case Study of Gorontalo Province Corn Commodity)
}

\author{
Ivan Rahmat Santoso ${ }^{1}$, Fahrudin Zain Olilingo $^{2}$ \\ Faculty of Economics, Gorontalo State University \\ Faculty of Economics, Gorontalo State University
}

\begin{abstract}
This study aims to determine the analysis of regional economic competitiveness in Gorontalo Province by looking at the value of export of superior corn commodity agriculture. This research covers regional areas in Gorontalo Province. The specific objective to be achieved is to obtain analytical data on the economic competitiveness of the Gorontalo Province in terms of the competitiveness of corn commodity exports. This list is expected to be an input for stakeholders to issue policies in increasing economic competitiveness in corn commodities in Gorontalo Province. This research was carried out in Gorontalo Province with objects in 5 districts and 1 city in Gorontalo Province detecting the competitiveness of each region. The method of analysis of this study uses the RCA (Revealed Comparative) comparative analysis method with the time of the 2013-2017 study. The results of the RCA (Revealed Comparative Advantage) analysis describe the competitiveness of Gorontalo Province's corn commodity exports experiencing fluctuations in which Gorontalo Province's corn commodity exports in 2014, 2015 and 2017 had strong competitiveness, while in 2013 and 2016 Gorontalo Province's maize commodity decreased due to that year Gorontalo Province did not export corn besides the absence of exports because domestic corn prices were quite good.
\end{abstract}

\section{Keywords: Competitiveness, Corn Leading Commodities}

The development of a region is an effort to increase regional competitiveness in the face of global competition. Where the existence of these demands has an impact on each region to continue to strive to accelerate regional economic development through regional economic development based on the potential of superior sectors owned by each region. On the other hand the development of a region sometimes experiences obstacles due to the uneven development in each region which results in disparities in community equality between regions in a region. According to Robbert Huggins a competitive area is believed to be able to run the economy well and have a positive impact on the surrounding area. The competitive region is reflected in its ability to continue to develop technology and knowledge to achieve stable growth 
and increase the welfare of its population (which is illustrated by the level of opinion and unemployment).

One of the leading sectors that can improve the competitiveness of a region is the productivity of the agricultural sector of corn. Corn production centers in Indonesia are in East Java, Central Java, Lampung, South Sulawesi, West Java, North Sumatra, and NTT (Agricultural Research Agency 2005). In addition, North Sulawesi, West Sumatra and Gorontalo are also included in the top 10 corn producing provinces (BPS 2014). Given the important role of corn, it is reasonable to prioritize the development of domestic corn production by increasing farming efficiency. In addition to fulfilling domestic needs, if this commodity farm has high competitiveness, Indonesia has the opportunity to become a corn exporter. For this reason, the competitiveness of the national corn farming business must be continuously improved.

Gorontalo Province has shown success in carrying out the process of building a rural economic structure, through government advocacy focused on efforts to develop corn commodities as an intensive business base at the farm level, as well as business people related to corn commodities. The increase in corn production from year to year has driven the growth of commodity exports. Data from the Agriculture Service said that in the period from January to May 2015, total corn exports to the Philippines reached 55,750 tons. Corn production at the end of 2014 until the beginning of 2015 was successful and abundant. The impact on collectors and exporters who can sell corn both for regional, national, and even export needs, while for exports from January to March it reached 17,424 tons and in April it reached 11,676 tons. The high corn export, he continued, indicated that Gorontalo corn production continued to increase with a high level of awareness of growing farmers' corn. The high production of corn is inseparable from the attention of both central and regional governments that continue to focus on developing corn as a superior commodity besides rice and soybeans. The government has provided various assistance such as the provision of free seeds, fertilizers and agricultural equipment to be provided to stimulate the desire of farmers to grow corn so that it can improve the welfare of farmers.

\section{Regional Competitiveness}

Competitiveness as the set of institutions, policies, and factors that determine the level of productivity of a 
country (Schwab and Porter, 2007). The definition of competitiveness depends on where the competitiveness is defined, whether at the micro level (company) or at the macro (national) level. Between the two concepts of competitiveness, the concept of regional competitiveness emerges, which has received great attention in recent years, this is because regions are key in the organization and governance of economic growth and welfare creation. According to Meyer-Stamer (2003), regional competitiveness is defined as the ability of a region to increase high income and the livelihoods of people in the region to a high standard of living. Whereas Huggins (2003) states that true regional competitiveness only occurs when sustainable growth is achieved at the level of labor that increases living standards.

National competitiveness in the aggregate is determined by regional competitiveness. Therefore national economic growth cannot be separated from regional economic performance. So that regional economic performance can be measured in the context of regional competitiveness. According to Lengyel (2007), there are two factors that determine regional competitiveness, namely direct and indirect factors. Development factors are direct and short-term factors that can affect economic output (GDP), labor productivity and the rate of working population. While indirect influences that affect regional competitiveness and in the long term include social, economic, environmental and cultural processes.

\section{Comparative Excellence}

The concept of comparative advantage is often used to explain the specialization of a country in producing goods and services. In addition, this concept can also be used for smaller areas such as provinces. According to Adam Smith, referenced in Hady (2004) that each country will obtain international trade benefits (gain from trade) because it specializes in production and exporting goods if the country has absolute advantage, and imports goods if the country has absolute disadvantages ( absolute disadvantage). However, this theory of absolute excellence can only explain a little of international trade at this time. In 1817, David Ricardo perfected the theory of superiority with the theory of comparative advantage through a book entitled "Principles of Political Economy and Taxation". The book contains an explanation of the theory of comparative advantage (The Law of Comparative 
Advantage). The law states that although a country is less efficient than (having absolute losses to) other countries in producing both commodities, there is still a basis for trade which is mutually beneficial for both parties. The first country must specialize in producing and exporting commodities that have smaller absolute losses (commodities with comparative advantages) and import commodities that have greater absolute losses (commodities that have large comparative losses) (Salvatore 1997).

\section{Theory of Revealed Comparative Advantage (RCA) \\ Revelead Comperative Advantage} (RCA) theory is used to analyze the comparative advantage of a commodity in a country. RCA is one of the $\mathrm{m}$, the method used to measure the export performance of a commodity from a country by evaluating the role of export of certain commodities in a country's total exports compared to the share of that commodity in world trade. The RCA concept was first introduced by Ballasa in 1965, which considered that a country's comparative advantage was reflected or revealed in its exports. At that time the concept of RCA was widely used in research reports and empirical studies which were used as indicators of the comparative advantage of a product and were used as a reference for specialization in international trade. From the RCA value can be seen how the competitiveness of a product whether its competitiveness is low or high. If the higher the value of RCA, the higher the competitiveness, and vice versa. Limitation of the value of ayitu competitiveness:

$$
\begin{aligned}
& \text { RCA }>1 \text { = high competitiveness } \\
& \text { RCA }<1=\text { low competitiveness }
\end{aligned}
$$

\section{METHODS}

This research will be carried out in Gorontalo Province which will detect the competitiveness of Gorontalo Province's corn commodity export rates for the period 2013-2017. This research will be conducted with the following stages of research:

1. Will examine the value of export of corn commodities in Gorontalo Province.

2. To reveal the level of competitiveness of the corn commodity in Gorontalo Province.

The method of collecting data and information used in this study is the method of documentation. The documentation method is to find data on things or variables in the form of notes, transcripts, books, newspapers, magazines, inscriptions, 
minutes of meetings, agendas, and so on (Arikunto, 2006). The documentation method is done by studying the documents published by the Central Bureau of Statistics, Bank Indonesia and related literature. In the next stage of regional data such as the types of commodities that are seeded, the location of development, infrastructure, human resources, government support, legal aspects are needed in the determination and creation of the master commodity master plan of Gorontalo Province.

\section{Analysis Model}

The analysis used is descriptive qualitative analysis and quantitative analysis. Analysis of comparative advantage of RCA (Revealed Comparative) With the following formula:

$$
R C A t=\frac{P t / Q t}{R t / S t}
$$

Note:

RCAt: Year Revealed Comperative Advantage year to $(\mathrm{t})$

Pt: Commodity Value of Gorontalo Province Corn Export year $(\mathrm{t})$

Qt: Total value of Gorontalo Province commodity exports year $(\mathrm{t})$
Rt: value of commodity for export of National Corn commodity year $(\mathrm{t})$

St: Value of total export of National commodity in year $(\mathrm{t})$

T: $2015, \ldots \ldots \ldots, 2017$

The value obtained from the RCA calculation varies, there are more, less or even equal to one. The greater the RCA value, the stronger the comparative advantage it has.

1. If the RCA value is greater than one, the corn export commodity in Gorontalo Province has a competitiveness above the average competitiveness of Indonesia.

2. If the RCA value is smaller than one, then the competitiveness of the commodity of corn in Gorontalo Province has a competitiveness below the average competitiveness of Indonesia.

3. If the RCA value is equal to one, then the competitiveness of the corn commodity in Gorontalo Province is equal to Indonesia's average competitiveness.

The RCA index is a comparison between the current RCA value and the previous year's RCA value. The RCA index formula is as follows: 


$$
\text { Indeks } R C A t=\frac{R C A t}{R C A t-1}
$$

Note:

RCAt Index: Performance of Gorontalo Province corn commodity exports period t. RCAt: Current RCA value ( $\mathrm{t}$ )

RCAt-1: Previous year's RCA value (t-1)

T: 2000,_...,2012

The RCA index value ranges from zero to infinity. The RCA index value equal to one means that there is no increase in RCA or the performance of Gorontalo Province's corn commodity exports has not changed from the previous year. If the RCA index value is smaller than one, it means a decline in the performance of Gorontalo Province's corn commodity exports. Whereas if the RCA index value is greater than one, the export performance of Gorontalo Province's corn commodity is higher than the previous year.

\section{RESULTS AND DISCUSSION}

\section{Revealed Comparative RCA Analysis}

From the calculation of RCA analysis for the last five years the following results are obtained.

Table 1. Results of revealed RCA (revealed comparative advantage)

\begin{tabular}{|c|c|c|c|c|c|c|}
\hline Year & $\begin{array}{l}\text { Gorontalo } \\
\text { Province Corn } \\
\text { Export Value } \\
\text { (US\$ ) }\end{array}$ & $\begin{array}{l}\text { Value of } \\
\text { Gorontalo } \\
\text { Province's } \\
\text { Non-Oil and Gas } \\
\text { Exports } \\
\text { (US\$ ) } \\
\end{array}$ & $\begin{array}{l}\text { Indonesian } \\
\text { Corn Exports } \\
\text { (US\$ ) }\end{array}$ & $\begin{array}{l}\text { The Total } \\
\text { Value of } \\
\text { Indonesia's } \\
\text { Non-Oil and Gas } \\
\text { Exports } \\
\text { (US\$ ) }\end{array}$ & $\begin{array}{l}\text { Corn } \\
\text { RCA } \\
\text { Value }\end{array}$ & Information \\
\hline 2013 & - & 5.280 .815 & 11,895 & 149918,8 & - & $\begin{array}{l}\text { Do not have } \\
\text { superiority }\end{array}$ \\
\hline 2014 & 8.516 .868 & 15.039 .395 & 13,264 & 145961,2 & 62.53 & Has advantages \\
\hline 2015 & 26.751.599 & 31.381.776 & 62,151 & 131791,9 & 18,07 & Has advantages \\
\hline 2016 & - & 28.406 .772 & 3,655 & 132080,8 & - & $\begin{array}{l}\text { Do not have } \\
\text { superiority }\end{array}$ \\
\hline 2017 & 186.83 & 1.575.507 & 4,622 & 153083,8 & 39,27 & Has advantages \\
\hline
\end{tabular}

Source: Processed Data

Note:

RCA> 1: Strong competitiveness

RCA <1: Weak Competitiveness

Based on the table, it can be seen that in 2013 until 2017 Gorontalo province's corn commodity fluctuated (up and down), where in 2013 and 2016 the RCA value was 0 , this was due to the fact that Gorontalo province did not export corn other than the absence exports because domestic corn prices are quite good. 
The highest RCA value is in 2014, with an RCA value of 62.53 , the lowest RCA value in 2015 with an RCA value of 18.07. The RCA value of Gorontalo Province corn commodity in 2014, 2015 and 2017 is greater than one (RCA> 1), so that the export value of the Gorontalo commodity of corn in that year has a comparative advantage. While the value of Gorontalo Province's corn commodity RCA in 2013 and 2016 did not have a comparative advantage.

Table 2. Gorontalo Province RCA Corn Export Index Results

\begin{tabular}{|c|c|}
\hline Year & RCA Index \\
\hline 2013 & - \\
\hline 2014 & - \\
\hline 2015 & 0,28 \\
\hline 2016 & 18,07 \\
\hline 2017 & 2,17 \\
\hline
\end{tabular}

Source: Processed Data

If the RCA index value is smaller than one, it means a decline in the performance of Gorontalo Province's corn commodity exports. Whereas if the RCA index value is greater than one, the export performance of Gorontalo Province's corn commodity is higher than the previous year. Based on the results of the RCA Index table it is known that in 2013-2017 the Gorontalo province corn commodity export index fluctuated. Gorontalo Province's corn commodity RCA index rose from 0.28 to 18.07 in 2016 . The increase illustrated that there was an increase in export performance in 2016 compared to the previous year. In the following year, in 2015, it can be said that Gorontalo Province's corn export performance has decreased. This is in accordance with the RCA index results that are less than one (RCA index $<1$ ) which is worth 0.28 in 2015 . In 2017 the RCA Index results are at 2,17 , this indicates that the performance of Gorontalo Province's corn exports has decreased. In 2013 and 2014 the RCA Index results were at number 0 , this was caused in 2013 there was no performance of Gorontalo Province corn exports.

\section{CONCLUSION}

The results of research data analysis that has been done, conclusions can be taken as follows:

1. RCA analysis results, Gorontalo Province's corn commodity exports in 2014, 2015 and 2017 have strong competitiveness because they have a greater than one RCA value each year.

2. The RCA index results, it was found that the competitiveness of Gorontalo Province's corn commodity exports in 
2016 increased by 18.07 and in 2017 decreased by 2, 17. In 2013 and 2014 the RCA Index results were at number 0 , this was caused in 2013 there was no performance of Gorontalo Province corn exports.

\section{SUGGESTION}

Based on the research and conclusions, the researchers tried to give the following suggestions:

1. For the Government

In order to remember the competitiveness of Gorontalo Province's corn commodity exports, I as a writer suggested that the government could support facilities ranging from transportation, coconut processing organizations, corn milling machines and better export strategies to improve the competitiveness of corn exports in Gorontalo Province.

2. For Farmers

Improving the skills of farmers in the production process and processing more creative results, the availability of superior seeds and other production facilities in order to produce quality production that is ready to compete in the international market.

\section{REFERENCES}

Abdullah, Peter dkk. (2002). "Daya Saing Daerah: Konsep dan Pengukurannya di Indonesia". Yogyakarta: BPFE.

Alisjahbana, Armida S., dkk. (2002). "Daya Saing Daerah, Konsep dan Pengukurannya dimIndonesia”, Yogyakarta, BPFE.

Afonso, Antonio. (2003). "Public Sector Efficiency: An International Comparison", European Central Bank Working Papers Series, No 242. http://ecb.europa.eu/pub/pdf/scpwps/ ecbwp242.pdf. Diakses tanggal 5 Juli 2013.

Ahmad Syakir Kurnia. (2006). "Model Pengukuran Kinerja dan Efisiensi Sektor Publik Metode Free Disposable Hull (FDH)”. Jurnal Ekonomi Pembangunan, Kajian Ekonomi Negara Berkembang, Hal 120. Fakultas Ekonomi Universitas Diponegoro Semarang.

Bank Indonesia. (2013). "Laporan Perkembangan Ekonomi Gorontalo". BI Gorontalo.

Budiharsono, Sugeng, (1989).

"Perencanaan Pembangunan Wilayah, Teori, Model Perencanaan, dan Penerapannya,Bogor”.

Badan Pusat Statistik. Gorontalo Dalam Angka Tahun 2017-2018, BPS Provinsi Gorontalo.

Boalemo Dalam Angka Tahun 2017-2018, BPS Provinsi Gorontalo. 
Bone Bolango Dalam Angka Tahun 2017-2018, BPS Provinsi Gorontalo.

Pohuwato Dalam Angka Tahun 2017-2018, BPS Provinsi Gorontalo.

Kabupaten

Gorontalo Dalam Angka Tahun 20172018, BPS Provinsi Gorontalo.

Dalam Angka Tahun 2017-2018, BPS

Provinsi Gorontalo.

Ibrahim, Yacob. (2009). "Studi Kelayakan Bisnis. Jakarta". Rineka Cipta

Irawati, Ira dkk. (2008). "Pengukuran Tingkat Daya Saing Daerah Berdasarkan Variabel Perekonomian Daerah, Variabel Infrastruktur dan Sumber Daya Alam, Serta Variabel Sumber Daya Manusia di Wilayah Provinsi Sulawesi Tenggara”. Bandung: Institut Teknologi Nasional. http://lib.itenas.ac.id/kti/?p=901.

Diakses tanggal 12 Juni 2013.

Kuncoro, Mudrajad (2002). "Analisis Spasial dan Regional. Studi Aglomerasi dan Kluster Industri Indonesia" UPP AMP YKPN Yokyakarta.

(2012). Ekonomika Aglomerasi: Dinamika dan Dimensi Spasial, UPP AMP YKPN Yokyakarta.

Olilingo, Fachrudin Zain. (2002). "Peranan Sektor Industri Dalam Perekonomian Wilayah Dan Dampaknya terhadap Distribusi Pemakaian Input dan Ketimpangan Antar Sektor Di Provinsi Sulawesi Tengah". Disertasi Program Pascasarjana Universitas Padjadjaran Bandung.
Sukirno, Sadono (1996). "Ekonomi Pembangunan” Borta Gorat: Medan.

Syafrizal (2012). "Ekonomi Wilayah Dan Perkotaan" PT. Raja Grafindo Persada: Depok.

Tambunan, Tulus. (1999). "Perkembangan Industri Skala Kecil Di Indonesia". PT. Mutiara Sumber Widya: Jakarta.

Tuwo, A. (2011). "Pengelolaan Ekowisata Pesisir dan laut: Pendekatan Ekologi, Sosial- Ekonomi, Kelembagaan, dan sarana wilayah". Brilian Internasional: Surabaya. 